\title{
Corrigendum
}

\section{Novelty Seeking and Stereotypic Activation of Behavior in Mice with Disruption of the Dat / Gene}

\author{
Vladimir M Pogorelov', Ramona M Rodriguiz', Megan L Insco', Marc G Caron² and William C Wetsel' \\ 'Departments of Psychiatry and Behavior Sciences, Medicine (Endocrinology), and Cell Biology, Mouse Behavioral and Neuroendocrine Analysis \\ Core Facility, Duke University Medical Center, Durham, NC, USA; ²Departments of Cell Biology and Medicine, Duke University Medical Center, \\ Durham, NC, USA
}

Neuropsychopharmacology (2005) 30, I772. doi:I 0.I038/sj.npp. I 300797

Correction to: Neuropsychopharmacology (2005) advance online publication, 27 April 2005; doi:10.1038/sj.npp. 1300724.
Following the publication of this article, the authors noted errors in the author affiliations. The correct affiliations are shown above. 